\title{
SDS-PAGE of Seed Protein Criteria in Relation to Taxonomy of Onobrychis Sect. Lophobrychis s. str. and the Egyptian Species
}

\author{
Maged Mahmoud Abou-El-Enain* \\ Biological Sciences and Geology Department, Faculty of Education, Ain Shams University, \\ Roxy (Heliopolis), P. C.11341, Cairo, Egypt
}

Received April 30, 2004; accepted May 27, 2004

\begin{abstract}
Summary SDS-PAGE of seed protein bands profile was recorded in 22 individuals of 6 species of Onobrychis from 6 populations, including the Egyptian species and most representatives of Sect. Lophobrychis. The produced data, in addition to the available morphological, cytological and the geographical characters in the literature were analyzed by the NTSYS program package using the UPGMA clustering method. The interspecific variability within the species studied of the section Lophobrychis was discussed; the genetic and morphological differences between the Egyptian species were assessed.
\end{abstract}

Key words Cytotaxonomy, Electrophoresis, Polyploidy, Protein profiles, UPGMA.

Onobrychis Miller is a forage genus, drought-resistant, nitrogen fixing and has been exploited to maintain soil productivity of wild pasture and as high-protein fodder plant for ruminants and equines (Lane et al. 2000). Their species are distributed in the temperate regions of Northern Hemisphere and extends from the Mediterranean region to Caucasia, the Zagros Mountains and central Asia with a centre of diversity in Northwest Asia (Yildiz et al. 1999, Aktoklu 2001). The genus belonging to the Tribe Hedysareae, Subfamily Paplionoideae of the Leguminosae comprises about 170 mostly perennial species (Aktoklu 2001), 8 sections and 2 subgenera (Boissier 1872, Sirjaev 1925, Yildiz et al. 1999). Only 2 species represent the genus in the Egyptian wild flora, namely $O$. crista-galli (L.) Lam. of Sect. Lophobrychis Hand.-Mazz., Subg. Onobrychis (Bunge) Grossh and O. ptolemaica (Delile) DC. of Sect. Hymenobrychis D.C., Subg. Sisyrosema Bunge (Ball 1968, Tackholm 1974, Boulos 1999).

The Sect. Lophobrychis has been a subject of much confusion mainly because of comprising the annual species of the genus (Handel-Mazzetti 1910, Sirjaev 1925) as well as the different approaches to species delimitation. Goldblatt (1981) pointed out that, only the species of Lophobrychis have $x=8$ whereas those of the whole genus have $x=7$ and considered the section as unspecialized. However, controversial chromosome counts even basic numbers have been reported within most species viz. $2 n=2 x=14,2 n=2 x=16$ and $2 n=4 x=28$ in O. aequidentata, $2 n=2 x=14$ and $2 n=2 x=16$ in O. caput-galli and $2 n=2 x=14$ and $2 n=2 x=16$ in the Egyptian O. crista-galli. AbouEl-Enain (2002) pointed out that the interspecific variability based on karyological criteria demonstrates a complexity of the evolutionary patterns of these species. Ashurmetov and Normatov (1998) reported interspecific variability in the embryological features of some Lophobrychis species that are only found in a comparatively small number of angiosperms. On the other hand, Magulaev (1995) and Yildiz et al. (1999) reported a close phylogenetic relationship between the Sect. Lophobrychis and its related Sect. Hymenobrychis based on cytological and fruit morphologi-

* Present address: Science Dept., Ibri College of Education, IBRI, OMAN, P.O.14, PC.516. E-mail: maged248@omantel.net.om, abouelenain@yahoo.com. 
cal characters, respectively.

Polyacrylamide gel electrophoresis technique in the presence of sodium dodecyle sulfate (SDS-PAGE) of seed proteins has a useful role in the identification and classification of various taxa (Paino et al. 1990, Ahmad and Slinkard 1992, Nath et al. 1997, Abou-El-Enain and Loutfy 1999, Badr et al. 2000). Except those of Cenci and Mizianty (1997) and Cenci et al. (2000), no studies have been made on the impact of seed protein electrophoretic criteria on the interspecific relationships in the genus Onobrychis. None of these studies have concentrated either on the Egyptian species or those of Sect. Lophobrychis. Using the seed protein electrophoretic criteria, the present work aimed at demonstrating the genetic and morphological differences between the Egyptian species, thereby establishing the taxonomic relationships between the species studied. In this analysis, available data on morphological, cytological characters as well as the geographical distribution are referred in considering numerical methods.

\section{Materials and methods}

In the present study, seeds of 22 individuals representing 6 species from 6 populations including the Egyptian species and most representatives of Sect. Lophobrychis were examined. The studied materials and their source, origin, geographical distribution and sectional delimitation (Yildiz et al. 1999) are given in Table 1. Taxonomic identification and nomenclature of the Egyptian species follow Tackholm (1974) and Boulos (1999). Voucher specimens are kept at the Herbarium of Biological Sciences and Geology Department, Faculty of Education, Ain Shams University, Egypt.

For extracting and analysing the total seed protein, SDS-PAGE technique was used as described by Badr et al. (2000). For creating the data matrix for computation, the distinguishable seed protein bands of the present study and the other criteria compiled from the literature i.e. morphological (Ball 1968, Tackholm 1974, Boulos 1999, Yildiz et al. 1999), geographical distribution (Table 1) and cytological (Abou-El-Enain 2002) were selected, scored and coded as indicated in Table 3. The relationship between the species studied was measured by calculating their average taxonomic distance (dissimilarity) and presented as phenograms based on the analysis for each of the morphological, seed protein and the all combined data sets (Figs. 2-4, respectively). These analyses were performed using the NTSYS program package for IBM-pc as described by Rohlf (1993). In the computer analyses, the species are numbered as indicated in Table 1.

\section{Results and discussion}

The micrograph revealing the produced SDS-PAGE banding patterns of seed protein analysis in the species studied is shown in Fig. 1, whereas the produced bands and their molecular mass (MW) are presented in Table 2. The selected 118 characters (40 SDS-PAGE) of this study and those obtained from the literatures (50 morphological, 26 geographical, 2 cytological) and their codes are given in Table 3. The produced phenograms illustrating the relationships (classifications) of the species studied are presented in Figs. 2-4, in which the characters analyses of the morphological data, seed protein data and the all combined data sets are presented, using the UPGMA clustering method.

The produced classification of the species studied based on the character analysis of the all combined data sets (Fig. 4) reveals a clear distinction and considerable linked characteristics among the species studied of the Sect. Lophobrychis, i.e. O. aequidentata (1), O. caput-galli (3), O. cristagalli (4) and O. pulchella (6). They are clustered together and distinguished from those of Sect. Hymenobrychis i.e. O. bobrovii (2) and O. ptolemaica (5) due to the presence of bands of numbers 14, 21 and 33 with molecular mass of 43.0, 32.3 and $20.5 \mathrm{kD}$, respectively, and absence of the bands of numbers 13, 19 and 35 with molecular mass of 47.7, 36.0 and 17.2 kD, respectively (Table 2). Such 
Table 1. The examined species; their source; origin; geographical distribution and sectional delimitation

\begin{tabular}{|c|c|c|c|c|}
\hline Species & Source & Origin & Geographical distribution & Section \\
\hline $\begin{array}{l}\text { 1) O. aequidentata }(\text { Smith) d'Urv. } \\
\text { (=Hedysarum aequidentatum } \\
\text { Smith }^{1}, \text { Onobrychis aequidentata } \\
\text { (Smith) d'Urv. subsp. foveolata } \\
\text { (DC.) Sirj. }{ }^{1}, \text { O. }{\text { cretica } \text { Desv. }^{2}, O .} \text {. } \\
\text { foveolata } \text { DC. }{ }^{1} \text { ) }\end{array}$ & IPK & France & $\begin{array}{l}\text { Asia: } \operatorname{Iran}^{3}, \operatorname{Iraq}^{4} \\
\text { Europe: Albania }^{1,2}, \text { Bulgaria }^{1,2,5} \text {, } \\
\text { Crete }^{1,2}, \text { former Yugoslavia }^{1,2} \text {, } \\
\text { France }^{1}, \text { Greece }^{1,2}, \text { Italy }^{1,2,6}, \text { Sicily }^{1} \text {, } \\
\text { Spain }^{1,2} \text {, Turkey in Europe } \\
\text { Middle East: Cyprus } \\
{ }^{1,2,} \text { Greece }^{1} \text {, } \\
\text { Turkey in Asia }\end{array}$ & Lophobrychis \\
\hline
\end{tabular}

\begin{tabular}{|c|c|c|c|c|}
\hline $\begin{array}{l}\text { 2) O. bobrovii Grossh. } .^{8,9} \\
\text { (=Xanthobrychis bobrovii (Grossh.) } \\
\text { Galushko. }{ }^{8} \text { ) }\end{array}$ & IPK & Daghestan & Asia: $\mathrm{USSR}^{9}$ & Hymenobrychis \\
\hline
\end{tabular}

\begin{tabular}{|c|c|c|c|}
\hline $\begin{array}{l}\text { 3) O. caput-galli }(\mathrm{L} .) \text { Lam. }{ }^{1,2,7} \\
\left.\text { (=Hedysarum caput-galli } \text { L. }^{1}\right)\end{array}$ & IPK & France & 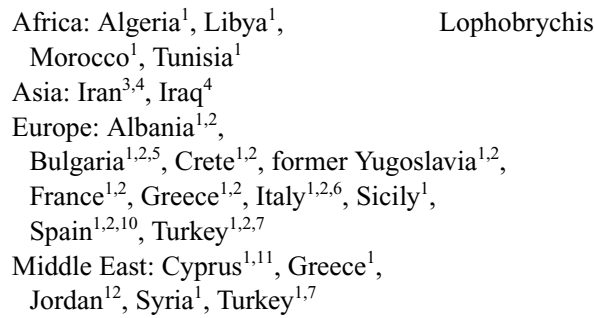 \\
\hline
\end{tabular}

\begin{tabular}{|c|c|c|c|c|}
\hline $\begin{array}{l}\text { 4) O. crista-galli }(\mathrm{L} .) \text { Lam. } .^{2,13} \\
\left(=\text { Hedysarum crista-galli } \mathrm{L}^{1}, \text { O. }\right. \\
{\text { armatus } \text { Pampan. }{ }^{14}, \text { O. ligulifera }}_{\left.\text {Pau }^{1}, \text { O. squarrosa } \text { Viv. }^{15}\right)}\end{array}$ & Wild & $\begin{array}{l}\text { Egypt, } \\
\text { Borg-Elarab, } \\
\text { Bahieg }\end{array}$ & $\begin{array}{l}\text { Africa: Algeria }{ }^{1}, \text { Egypt }^{1}, \text { Libya }^{1} \text {, } \\
\text { Morocco }^{1}, \text { Tunisia }^{1} \\
\text { Asia: } \operatorname{Iran}^{3}, \text { Iraq }^{4} \\
\text { Europe: France } \\
\text { Middle East: } \text { Cyprus }^{1}, \text { Greece }^{1} \text {, } \\
\text { Jordan }^{1}, \text { Syria }^{1}, \text { Sinai }^{1}, \text { Turkey }^{1}\end{array}$ & Lophobrychis \\
\hline
\end{tabular}

\begin{tabular}{|c|c|c|c|c|}
\hline $\begin{array}{l}\text { 5) Onobrychis ptolemaica (Del.) DC. }{ }^{1} \\
\text { (=Hedysarum ptolemaicum Delile }{ }^{13} \text {, } \\
\text { Onobrychis ptolemaica (Del.) DC. } \\
\text { subsp. macroptera } \text { C. Towns. }{ }^{1}, O . \\
\text { lanata } \text { Boiss. }{ }^{13}, \text { O. olivieri Boiss. }{ }^{13} \text { ) }\end{array}$ & Wild & $\begin{array}{l}\text { Egypt, } \\
\text { K. 65th } \\
\text { Cairo-Suez } \\
\text { Road }\end{array}$ & $\begin{array}{l}\text { Africa: Egypt } t^{1,13} \\
\text { Middle East: Palestine }{ }^{1} \text {, } \\
\text { Lebanon }^{1}, \text { Turkey }^{1}\end{array}$ & Hymenobrychis \\
\hline
\end{tabular}

\begin{tabular}{|c|c|c|c|c|}
\hline $\begin{array}{l}\text { 6) Onobrychis pulchella } \text { Schrenk }^{3,7} \\
\text { (=Onobrychis alba (Waldst. \& Kit.) } \\
\text { Desv. subsp. laconica (Orph. ex } \\
\text { Boiss.) Hayek }{ }^{2}\end{array}$ & IPK & Turkmenistan & $\begin{array}{l}\text { Asia: Afghanistan } \\
\operatorname{Iran}^{17}, \mathrm{USSR}^{9}\end{array}$ & Lophobrychis \\
\hline
\end{tabular}

(1) Greuter, W. et al. (eds.) 1989. Mediterranean flora checklist. Willdenowia 19: 27-48; (2) Ball, P. W. 1968. (3) Rechinger, K. H. 1984. Flora Iranica. Papilionaceae II, Graz Academy of Science; (4) Townsend, C. and Guest, E. 1974. Flora of Iraq, Vol. 3, Ministry of Agriculture, Baghdad; (5) Jordanov, D. (ed.) 1976. Flora Reipublicae Popularis Bulgaricae, 6 [1]-590; (6) Pignatti, S. 1982. Flora Italica. Edagicole, Bologna; (7) Davis, P. H. 1970. Flora of Turkey \& the East Aegean Islands, Vol. 3, Edinburgh University Press, Edinburgh, 560-589; (8) Czerepanov, S. K. 1981. Plantae Vasculares, Sosudistye Rasteniia SSSR. Leningrad; (9) Komarov, V. L. (ed.) 1948. Flora of the USSR. Vol. xiii, [1]-588, Izdatel'stvo Akademii 'Nauka' SSSR, Leningrad; (10) Bolos, O. and Vigo, J. 1984. Flora de les Paisos Catalans. Vol. 1, Editorial barcino, Barcelopa, [1]-736; (11) Meikle, R. D. 1977. Flora of Cyprus. Vol. 1, Bentham Moxon Trust, Royal Botanic Gardens, Kew, 1: 1-832; (12) Zohary, M. and Feinbrun-Dothan, N. 1972. Flora of Palestina, Part 2. The Israel Academy of Sciences and Humanities, Jerusalem; (13) Boulos, L. 1999. see References (14) Jafri, S. M. 1980. Fabaceae. In: Flora of Libya, Pt. 86: 1-147. Al Faateh University. Tripoli; (15) Tackholm, V. 1974. see References (16) Kitamura, S. 1960. Flora of Afghanistan. Research of Kyoto University Expedition. Vol. 2; (17) Parsa, A. 1948. Flore de l'Iran. Vol. 2. Teheran: Imprimerie Mazaheri. IPK=The Institute of Plant Genetic \& Horticulture gene bank, Gatersleben, Germany. 
relationships are confirmed by the character analyses of all the used data sets (Figs. 2-4). Morphologically, they are characterized as follows: appressed-hairy surface; stems erect or ascending; stipules $0.4-0.6 \mathrm{~cm}$, acuminate, scarious with a green median nerve; leaflets 5-9 pairs, $0.6-1.2 \times 0.1-0.3 \mathrm{~cm}$, short-petioliolate, oblong to linear, the apex truncate-mucronate; peduncles as long as the subtending leaf; racemes $2-10$-flowered; calyx teeth $0.5-0.6 \mathrm{~cm}$; corolla as long as the calyx, pink or white; pod shows ventral and dorsal asymmetry, $1-1.2 \times 0.8-1 \mathrm{~cm}$, oblong to hemispherical, compressed, with dorsally crest, setae, spins; valves pubescent; seeds $0.2,0.3 \times 0.3 \mathrm{~cm}$, compressed, smooth, brown (Ball 1968, Boulos 1999, Yeldiz et al. 1999). Embryologically, they are characterized by the anomalous microsporogenesis and pollen grain development and the formation of the embryosac long before anthesis and formation of endosperm haustoria (Ashurmetov and Normatov 1998).

On the other hand, the seed protein data (Figs. 1 and 3; Table 2) of the species studied of the section Lophobrychis revealed heterogeneity in the band distribution in the protein profiles. The diploid and polyploid species are distinguished each other at relatively small values of dissimilarity levels and could be characterized one another by a unique band in their profiles. $O$. aequidentata $(2 n=2 x=16), O$. caput-galli $(2 n=4 x=28)$ and O. crista-galli $(2 n=4 x=32)$ are characterized by presence of a protein band of the number 28,34, and 26 with molecular mass of 25.3, 18.5 and $27.0 \mathrm{kD}$, respectively, whereas $O$. pulchella $(2 n=4 x=32)$ is characterized by absence of the protein band number 4 with molecular mass of $69.5 \mathrm{kD}$. Thus, the produced protein banding patterns are species specific and are compatible with those of other lines of taxonomic evidence in demonstrating the interspecific variability among the species studied of Sect. Lophobrychis.

Investigation of the geographical distribution data of the species studied of the section Lophobrychis (Table 1) in relation to their chromosome counts (Abou-El-Enain 2002) revealed that they are distributed in about 26 different coun-
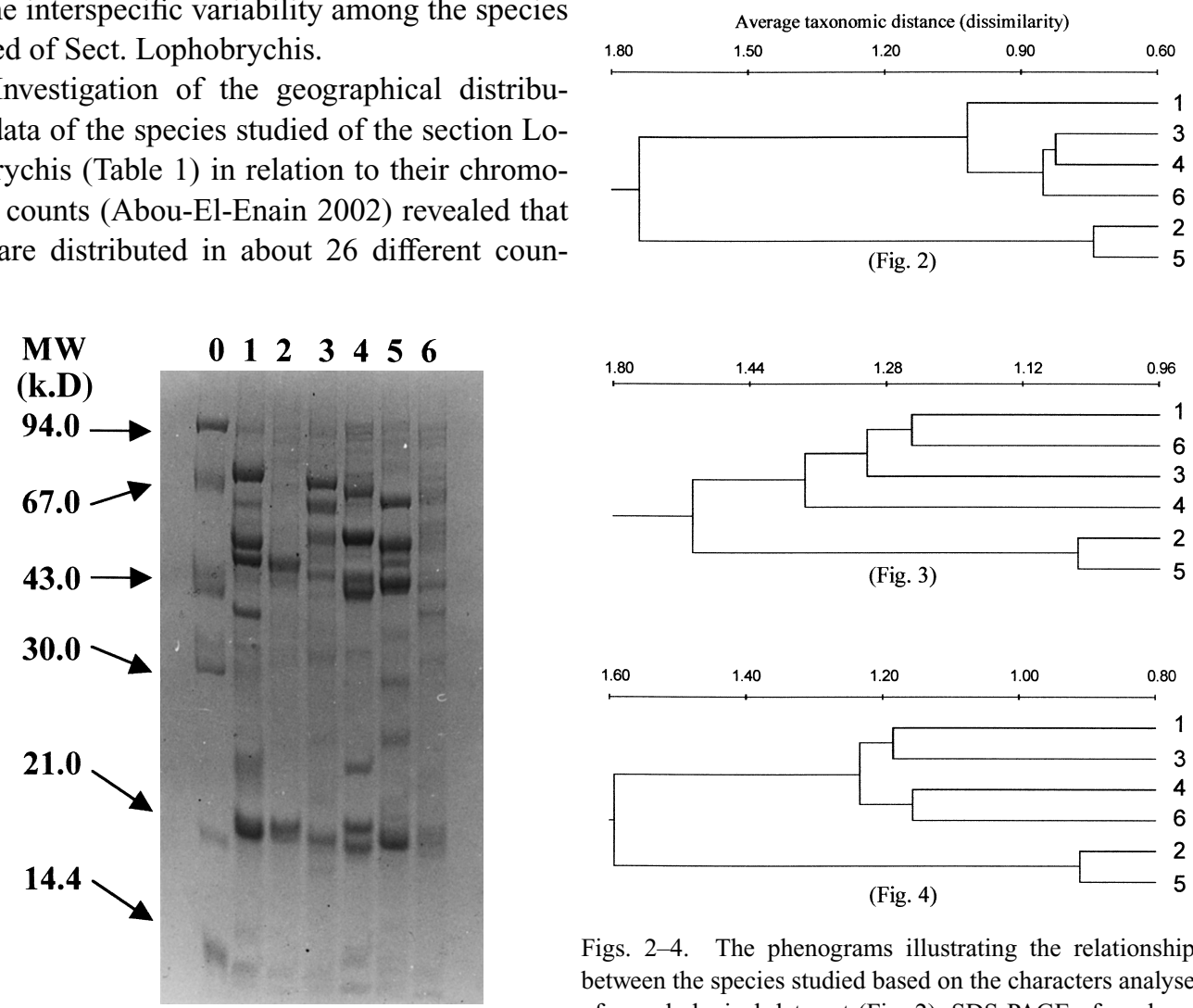

Figs. 2-4. The phenograms illustrating the relationships between the species studied based on the characters analyses of morphological data set (Fig. 2), SDS-PAGE of seed pro-

Fig. 1. Banding patterns of seed protein analysis using teins data set (Fig. 3) and all combined data sets (Fig. 4) SDS-PAGE technique (0, Marker; $1, O$. aequidentata; $2, O$. using UPGMA clustering method (1, O. aequidentata; $2, O$. bobrovii; 3, O. caput-gall; 4, O. crista-galli; 5, O. ptole- bobrovii; 3, O. caput-gall; 4, O. crista-galli; 5, O. ptolemaica; 6, O. pulchella). maica; 6, O. pulchella). 
Table 2. The produced banding patterns in the seed protein electrophoretic profiles of the species studied as scored from Fig. 1

\begin{tabular}{|c|c|c|c|c|c|c|c|}
\hline Band & MW & 1 & 2 & 3 & 4 & 5 & 6 \\
\hline No. & $(\mathrm{kD})$ & O. aequidentata & O. bobrovii & O. caput-galli & O. crista-galli & O. ptolemaica & O. pulchella \\
\hline 1 & 94.0 & -+- & -+- & --- & --- & --- & --- \\
\hline 2 & 78.8 & & & --- & --- & & --- \\
\hline 3 & 73.4 & --- & -+- & & --- & --- & --- \\
\hline 4 & 69.5 & +++ & & --- & -+- & & \\
\hline 5 & 67.0 & & -+- & +++ & --- & --- & --- \\
\hline 6 & 63.4 & --- & --- & & +++ & & --- \\
\hline 7 & 61.0 & +++ & & +++ & --- & +++ & -+- \\
\hline 8 & 59.5 & & --- & --- & --- & --- & --- \\
\hline 9 & 57.2 & -+- & & --- & & & --- \\
\hline 10 & 55.2 & & & +++ & +++ & & --- \\
\hline 11 & 53.5 & +++ & --- & & --- & +++ & --- \\
\hline 12 & 51.2 & +++ & & --- & --- & --- & --- \\
\hline 13 & 47.7 & & +++ & & & +++ & \\
\hline 14 & 43.0 & -+- & & +++ & +++ & & --- \\
\hline 15 & 42.3 & --- & --- & & --- & +++ & -+- \\
\hline 16 & 40.5 & & --- & --- & +++ & --- & \\
\hline 17 & 38.5 & +++ & & --- & & & -+- \\
\hline 18 & 37.2 & & --- & & & & \\
\hline 19 & 36.0 & & --- & & & --- & \\
\hline 20 & 35.2 & & & & & --- & \\
\hline 21 & 32.3 & --- & & -+- & --- & & --- \\
\hline 22 & 31.0 & --- & --- & & & --- & \\
\hline 23 & 30.0 & --- & --- & & & --- & \\
\hline 24 & 29.0 & & & & & --- & --- \\
\hline 25 & 28.6 & & --- & --- & & -+- & \\
\hline 26 & 27.0 & & & & +++ & & \\
\hline 27 & 26.4 & -+- & & & --- & & \\
\hline 28 & 25.3 & --- & & & & & \\
\hline 29 & 24.0 & & --- & --- & & -+- & \\
\hline 30 & 23.0 & --- & -+- & & --- & --- & --- \\
\hline 31 & 22.0 & +++ & --- & & +++ & --- & --- \\
\hline 32 & 21.0 & & --- & -+- & --- & +++ & +++ \\
\hline 33 & 20.5 & --- & & --- & +++ & & --- \\
\hline 34 & 18.5 & & & --- & & & \\
\hline 35 & 17.2 & & --- & & & --- & \\
\hline 36 & 16.2 & -+- & --- & --- & & --- & \\
\hline 37 & 15.5 & --- & & & --- & & --- \\
\hline 38 & 14.4 & & --- & & --- & --- & --- \\
\hline 39 & 13.0 & -+- & & --- & & & \\
\hline \multicolumn{2}{|c|}{ Total band no. } & 22 & 21 & 20 & 23 & 23 & 22 \\
\hline
\end{tabular}

$\mathrm{MW}=$ Molecular mass, $\mathrm{kD}=$ kilo Dalton, Blank=absent, $+++=$ deep dark, $-+-=$ dark to medium, $---=$ faint.

tries as native or introduced plants. All of them are recorded in Iran, Iraq and Turkey where the centre of diversity is found in Northwest Asia. They are extend regularly as far as Mediterranean countries either in East Europe or in North Africa where they are recorded as introduced plants (Ashurmetov and Normatov 1998). The most frequent species is O. caput-galli $(2 n=4 x=28 ; 22$ countries), followed by $O$. aequidentata $(2 n=2 x=16 ; 15$ countries), O. crista-galli $(2 n=4 x=32 ; 15$ countries) and the least common one is $O$. pulchella $(2 n=4 x=32 ; 3$ countries). These data besides the recorded role of the aneuploidy in the Lophobrychis evolution and the presence of polyploidy in 
Table 3. The 118 characters used in the present study and their codes for the numerical analyses

\section{Morphological characters:}

Whole Plant: (01) Habit: perennial =0, annual =1; (02) Height: $<30 \mathrm{~cm}=0,30-40 \mathrm{~cm}=1,40-50 \mathrm{~cm}=2,50-60 \mathrm{~cm}=3$, $>60 \mathrm{~cm}=4$;

Stem: (03) Branched base: absent $=0$, present $=1$; (04) Surface: glabrous $=0$, pubescent $=1$, appressed-hairy $=2$; (05) Woody base: absent $=0$, present $=1$.

Stipules: (06) Length: $<0.4 \mathrm{~cm}=0,0.4-0.6 \mathrm{~cm}=1,0.6-0.8 \mathrm{~cm}=2,>0.9 \mathrm{~cm}=3$; (07) Shape: triangular $=0$, triangular acuminate $=1 ;(08)$ Surface: glabrous $=0$, pubescent $=1$, scarious with a green median nerve $=2$.

Leaves: (09) Petiole length: $<0.8 \mathrm{~cm}=0$, about $1.2 \mathrm{~cm}=1$; (10) Diameter: $4-12 \mathrm{~cm}=0,6-14 \mathrm{~cm}=1$.

Leaflets: (11) Pairs number: less than $8=0$, more than $8=1$; (12) Diameters: $>0.7-1.8 \times 0.3-0.8 \mathrm{~cm}=0$, about $0.7-1.8 \times 0.3-0.8 \mathrm{~cm}=1 ;<0.8-1.8 \times 0.3-0.8 \mathrm{~cm}=2$; (13) Shape: oblong-elliptical $=0$, elliptical to linear $=1 ;(14)$ Apex shape: acute or obtuse $=0$, truncate-mucronate $=1 ;(15)$ Upper surface: glabrous $=0$, patent hairs $=1 ;(16)$ Lower surface: hairy $=0$, villous $=1$.

Peduncles: (17) Length: shorter than subtending leaves in flower $=0$, equaling the subtending leaves $=1$, longer than the subtending leaves $=2$, much longer than the subtending leaves $=3$; (18) Elongation in fruiting: absent $=0$, present $=1$.

Racemes: (19) Flowers number: many-flowered $=0,2-3$ flowered $=1$.

Bracts: (20) Length: $<0.5 \mathrm{~cm}=0$, about $0.5 \mathrm{~cm}=1 ;>0.5 \mathrm{~cm}=2$.

Pedicels: (21) Length: $<0.25 \mathrm{~cm}=0,0.26-0.35 \mathrm{~cm}=1,0.36-0.45 \mathrm{~cm}=2,>0.45 \mathrm{~cm}=3$.

Calyx: (22) Length: $<0.6 \mathrm{~cm}=0,0.6-0.65 \mathrm{~cm}=1,0.65-0.75 \mathrm{~cm}=2,>0.75 \mathrm{~cm}=3$, (23) Surface: glabrous $=0$, pubescent $=1$, hairy $=2 ;(24)$ Teeth length: shorter than the tube $=0$, as long as the tube $=1$, longer than the tube $=2 ;(25)$ Teeth shape: lanceolate $=0$, narrowly lanceolate $=1$, triangular $=2$.

Corolla: (26) Color: white $=0$, yellow with brown veins $=1$, pink $=2$, reddish-purple $=3$; (27) Length: $<0.7 \mathrm{~cm}=0$, $0.7-0.9 \mathrm{~cm}=1,0.9-1.1 \mathrm{~cm}=2,1.1-1.3 \mathrm{~cm}=3,>1.3 \mathrm{~cm}=4$.

Ovary: (28) Stalk: sessile $=0$; stalked $=1$; (29) Length: shorter than the calyx $=0$, as long as the calyx $=1$.

Pod: (30) Diameter: $<1-1.2 \times 0.8-1 \mathrm{~cm}=0,>1-1.2 \times 0.8-1 \mathrm{~cm}=1$; (31) Shape: orbicular $=0$, oblong to hemispherical $=1$;

(32) Compression: absent $=0$, present $=1$; (33) Valves surface: densely villous $=0$, hairy $=1$; (34) Segment number: one $=0$, two or more $=1$; (35) Faveole: partly ordered at least 3-4 rows $=0$, ordered $=1 ;$ (36) Number of first faveole row: with 2 faveoles $=0$, with 3 or more faveoles $=1$; (37) Number of large faveole on the first row: with 1 large faveole $=0$, with 2 large faveoles $=1$; (38) Ventral spine of large faveole: absent $=0$, present $=1$; (39) Faveolate crest of fruit: absent $=0$, present $=1$; (40) Border of fruit: $a b s e n t=0$, present $=1$; (41) Subcanaliculate margin of fruit: absent $=0$, present $=1$; (42) Spines or setae on the margin: Spines present as 1 row $=0$, Spines or setae present as 2 rows symmetrically (on upper and under sides) $=1$; (43) Marginal vein and spines border length: the same $=0$, Variable $=1$; (44) Structure of the marginal spines or setae: Spine or setae absent or setae present and setae not widened $=0$, Spine present and quite widened at the base $=1 ;(45)$ Curvation of fruit: ventral suture straight $=0$, ventral suture fully curved $=1$.

Seeds: (46) Diameter: $\leq 0.3 \times 0.3 \mathrm{~cm}=0,>0.3 \times 0.3 \mathrm{~cm}=1$; (47) Compression: absent $=0$, present $=1$; (48) Surface: smooth $=0$, rough $=1$; (49) Color: yellowish brown $=0$, brown $=1$, dark brown $=2$.

Ovule: (50) Number: one $=0$, two or more $=1$.

II. Seed protein characters: The characters from 51 to 89 and 90 represents the recorded bands and their total numbers, respectively as indicated in Table 1 . These are coded as follows: absent $=0$, deep dark $=1$, dark to medium $=2$, faint $=3$; total number of bands: $20=0,21=1,22=2,23=3$.

III. Geographical distribution: The absence or presence of the species in each of the following country is coded 1 or 0, respectively: (91) Algeria; (92) Egypt; (93) Libya; (94) Morocco; (95) Tunisia; (96) Afghanistan; (97) Iran; (98) Iraq; (99) USSR; (100) Albania; (101) Bulgaria; (102) Crete; (103) France; (104) Greece; (105) Italy; (106) Sicily; (107) Spain; (108) Turkey in Europe; (109) Yugoslavia (former); (110) Cyprus; (111) Jordan; (112) Lebanon; (113) Palestine; (114) Balkan Peninsula; (115) Syria; (116) Turkey in Asia.

IV. Cytological characters: (117) Basic chromosome number $(x): x=7=0, x=8=1$; (118) Diploid chromosome number $(2 n): 2 n=16=0,2 n=28=1,2 n=32=2$.

a percentage of more than $60 \%$ among the whole genus (Abou-El-Enain 2002) confirm the comparatively highly derived organization of the species studied of Sect. Lophobrychis.

Comparison of the produced classifications (Figs. 2-4) revealed a considerable consistency in separation of the two Egyptian species $O$. crista-galli (No. 4) and O. ptolemaica (No. 5) among the two different groups of the species studied. The seed protein data revealed that the Egyptian species 
have 13 bands in common, each has 10 different bands and the similarity between the two species is about $56 \%$. O. crista-galli differs from $O$. ptolemaica in the presence of the bands numbered 2, 4, 5, $10,14,21,26,27,33$ and 37, with molecular mass of 78.8, 69.5, 63.4, 55.2, 43.0, 32.3, 27.0, 26.4, 20.5 and $15.5 \mathrm{kD}$, respectively. $O$. ptolemaica differs from $O$. crista-galli in the presence of the bands numbered 13, 19, 20, 22, 23, 24, 25, 29, 35 and 36 with molecular mass of 47.7, 36.0, 35.2, $31.0,30.0,29.0,28.6,24.0,17.2$ and $16.2 \mathrm{kD}$, respectively.

Morphologically, O. ptolemaica is characterized by racemes $10-15 \mathrm{~cm}$, many-flowered, pod orbicular, flattened, densely villous, whereas $O$. crista-galli is characterized by racemes $2-4 \mathrm{~cm}, 2-5-$ flowered and pod oblong to hemispherical, compressed, with a crest of irregular spinose lobes $0.2-0.5 \mathrm{~cm}$. Geographically, O. ptolemaica is infrequent in the Sinai Peninsula (i.e. the West Asian part of Egypt) and the Desert East of the Nile, while O. crista-galli is frequent in the Mediterranean coastal strip from Port Said to the border with Libya near El-Sollum of the Egyptian territories. Cytologically, O. ptolemaica is characterized by its diploid chromosome count of $2 n=2 x=16$ and the xerophytic nature. On the other hand, $O$. crista-galli is characterized by its annual habit, a tetraploid chromosome count of $2 n=4 x=32$, and a mesophytic nature. These data support the taxonomic delimitation of $O$. crista-galli and $O$. ptolemaica in the two Sections Lophobrychis and Hymenobrychis, respectively, that previously inferred by the systematic studies based on the embryological (Ashurmetov and Normatov 1998), fruit morphological (Yeldiz et al. 1999) and cytological criteria (Heyn 1962, Abou-El-Enain 2002).

The previous studies on the genus Onobrychis revealed that $O$. caput-galli exhibits common morphological, anatomical and cytological characters with the two Egyptian species. These characters are the measurements of fruit in length, width, thickness and number of thorns as well as the anatomical characteristics of the seed coats (Cenci et al. 2000) and the 2 different cytotypes regarding the chromosome numbers i.e. $2 n=14,16$ based on $x=7$ and 8, respectively, (Slavivk et al. 1993, Abou-El-Enain 2002) in addition to a high ecological amplitude as revealed by the wide range of distribution in different habitats (Ashurmetov and Normatov 1998). This reveals the possibility of considering O. caput-galli as evolutionary linkage in the diversity of the two Egyptian species.

\section{References}

Abou-El-Enain, M. 2002. Chromosomal criteria and their phylogenetic implications in the genus Onobrychis Mill. sect. Lophobrychis (Leguminosae), with special reference to Egyptian species. Bot. J. Linn. Soc. 139: 409-414.

- and Loutfy, M. 1999. SDS-PAGE of seed proteins and SEM of seed coat surface in Caesalpinia gilliesii, C. pulcherrima, C. sepiaria and Delonix regia (Leguminosae-Caesalpinioideae). Taeckholmia 19: 37-52.

Ahmad, M. and Slinkard, A. E. 1992. Genetic relationships in the genus Cicer L. as revealed by polyacrylamide gel electrophoresis of seed storage proteins. Theor. and Appl. Genetics 84: 688-692.

Aktoklu, E. 2001. Two new varieties and a new record in Onobrychis from Turkey. Turkish J. Bot. 25: 359-363.

Ashurmetov, O. A. and Normatov, B. A. 1998. Embryology of annual species of the genus Onobrychis Mill. Flora 193: 259-267.

Badr, A., El-Shazly, H. H. and Abou-El-Enain, M. M. 2000. Seed protein diversity and its implications on the relationships in the genus Lathyrus. Proceedings of the first International Conference of Biological Sciences, (May, 2000), 1-15. Tanta University, Egypt.

Ball, P. W. 1968. Onobrychis Mill. In: Tuten T. G., Heywood V. H., Burges N. A., Moore D. M., Valentine S. M. and Webb D. A. (eds.). Flora Europeaea V2, Cambridge University Press, pp. 187-191.

Boissier, P. E. 1872. Flora Orientalis. Sive Enumarito Plantarum in Oriente: A Graecia et Aegypto ad Indiae fines hueusque observatarum. Vol. 2, Genevae.

Boulos, L. 1999. Flora of Egypt. Al Hadara Publishing, Cairo, pp. 338-339.

Cenci, C. A. and Mizianty, M. 1997. Some morphometric and chemotaxonomic features in the taxonomy of Onobrychis from Poland. Fragmenta Floristica et Geobot. 42: 401-404.

-, Bassi, G., Ferranti, F. and Romano, B. 2000. Some morphometric, anatomical and biochemical characteristics of fruits and seeds of Onobrychis spp. in Italy. Plant Biosystems 134: 91-98.

Goldblatt, P. 1981. Cytology and the phylogeny of Leguminosae. In: Polhill, R. M. and Raven, P. H. (eds.). Advances in 
Legume Systematics. Part 2. Royal Botanic Gardens, Kew, pp. 427-463.

Hadel-Mazzetti, H. 1910. Revision der Balkanischen und Vorderasiatischen Onobrychis Arten aus der Sektion Eubrychis. Osterreich. bot. Zeitschr. 60: 64-71.

Heyn, C. C. 1962. On the cytotaxonomy of Onobrychis crista-galli (L.) Lam. and O. squarrosa Vivi. Bull. Res. Coun. Israel 3: 177-182.

Lane, G. P., Koivisto, J. M., Phillips, M., Terrill, T., Belesky, D. and Berdahl, J. 2000. A reassessment of the potential of sainfoin (Onobrychis viciifolia) as a forage crop for the United Kingdom. In: Phillips, M. and Terrill, T. (eds.). Proceedings of American Forage and Grassland Council, 37th North American Alfalfa Improvement Conference, 202-205. Georgetown, U.S.A.

Magulaev, A. Y. 1995. Chromosome numbers, distribution and some taxonomical problems in North Caucasus species of Onobrychis subgenus Hymenobrychis (Fabaceae). The Botanical Journal (Russia) 80: 55-59.

Nath, P., Ohri, D., Jha, S. S. and Pal, M. 1997. Seed protein electrophoresis of wild and cultivated species of Celosia (Amaranthaceae). Gen. Res. Crop Evol. 44: 241-245.

Paino, D., Urzo, M., Pedalino, M., Grillo, S., Rao, R., Tucci, M., D’Urzo, M. P., Ng, N. Q. and Monti, L. M. 1990. Variability in major seed proteins in different Vigna species. Cowpea Gen. Res. 19: 90-100.

Rohlf, F. J. 1993. NTSYS-pc, Numerical taxonomy and multivariate analysis system. New York: Exeter Computers.

Sirjaev, G. 1925. Onobrychis generis revisio critica. Publications of the Faculty of Science, University of Masaryk 56: 96-97.

Slavivk, B., Jarolivmovav, V. and Chrtek, J. 1993. Chromosome counts of some plants from Cyprus. Candollea 48: 221-230.

Tackholm, V. 1974. Student's Flora of Egypt. Cairo: Anglo Egyptian Bookshop.

Yildiz, B., Ciplak, B. and Aktoklu, E. 1999. Fruit morphology of sections of the genus Onobrychis Miller (Fabaceae) and its phylogenetic implications. Israel J. Plant Sci. 47: 269-282. 